Papers and Proceedings of the Royal Society of Tasmania, Volume 118, 1984

(ms. received 2.VIII.1983)

\title{
MILLIPEDES FROM AUSTRALIA, 7: THE IDENTITY OF THE GENUS LISSODESMUS CHAMBERLIN, WITH THE DESCRIPTION OF FOUR NEW SPECIES FROM TASMANIA (DIPLOPODA, POLYDESMIDA, DALODESMIDAE)
}

\author{
by C.A.W. Jeekel
}

Instituut voor Taxonomische Zoölogie,

Zoölogisch Museum, Universiteit van Amsterdam

(with fifteen text-figures)

ABSTRACT

JEEKEL, C.A.W., 1984 (31 viii): Millipedes from Australia, 7: The identity of the genus Lissodesmus Chamberlin, with the description of four new species from Tasmania (Diplopoda, Polydesmida, Dalodesmidae). Pap. Proc. R. Soc. Tasm., 118: 85-102. https://doi.org/10.26749/rstpp.118.85ISSN 0080-4703. Instituut voor Taxonomische Zoölogie, Zoölogisch Museum, Universiteit van Amsterdam, The Netherlands.

The monotypic Lissodesmus modestus Chamberlin, 1920, is redescribed from nearly topotypical material, and four new species, L. adrianae, L. alisonae, L. perporosus and $L$. margaretae, all from Tasmania are added to the genus. Australopeltis Johns, 1964, based on Pseudoprionopeltis martini Carl, 1902, from Victoria, is considered a synonym of Lissodesmus (new synonymy). Some remarks are made on the classification of the nonparadoxosomatid Polydesmida of Tasmania.

\section{INTRODUCTION}

During a trip through Tasmania towards the end of November 1980 (Jeekel 1981), the author and his wife at various localities collected a number of dalodesmid millipedes, which were conspicuous by the frequency of their occurrence, their relatively major size, and their light brown-orange colour. In the field these specimens looked very much alike, apart from some slight differences in size, but upon closer examination no less than four distinct species were recognized.

Up to now six species and as many genera of the order Polydesmida not belonging to the family Paradoxosomatidae have been described from Tasmania. All are known only from their type locality and material and have been described by Silvestri (1910), Chamberlin (1920), Verhoeff (1936) and Jeekel (1982). These are: Asphalidesmus leae Silvestri, 1910 (Hobart); Atopodesmus parvus Chamberlin, 1920 (locality unknown); Lissodesmus modestus Chamberlin, 1920 (Russel1 Falls); Tasmanodesmus hardyi Chamberlin, 1920 (1ocality unknown); Tasmaniosoma armatum Verhoeff, 1936 (Lake Leake); and Gasterograma psi Jeeke1, 1982 (Hellyer Gorge).

The first two genera are not considered in the discussion on the generic position of the collected species. As noted below, there is much evidence to support the exclusion of Asphalidesmus and Atopodesmus from the Dalodesmidae, thus leaving the four remaining genera as true members of the family.

Among these, Gasterograma is quite distinct from the material at hand. Its cylindrical body lacks paranota almost completely, the relative length and width of the podomeres of the male are different and the gonopods are quite characteristic. Its status was amply discussed in a previous paper of the present series.

Tasmaniosoma is distinct in having 19 body somites and the long tarsi exceed all other individual podomeres in length. The genus is well characterized by the structure of the gonopods which have been illustrated.

Unfortunately, no illustrations have been published of the gonopods of Tasmanodesmus and Lissodesmus, and on that account the position of these two genera within the family 


\section{Four New Species of Millipedes from Tasmania}

Dalodesmidae is uncertain. With regard to Tasmanodesmus it must be concluded that the description of this genus and of its type-species cannot be reconciled with the material at hand. Chamberlin described the gonopods as "telopodites long, split from the distal end to near middle of length into three branches, the middle (seminiferous) of these the 1ongest, slenderly tipped, branches not coiled". This statement does not tally with the structure of the gonopods in the collected species, in which the solenomerite is just one of several shorter branches. Moreover, the legs in Tasmanodesmus are described as having long tarsi as in Tasmaniosoma.

Therefore, the only generic name possibly eligible for the collected species is Lissodesmus. Fortunately, specimens collected quite near the type locality of L. modestus match its description quite well and there is little doubt that Lissodesmus is the proper generic name for the four species.

Moreover, the four species are clearly congeneric with Pseudoprionopeltis martini Car1, 1902, described from Melbourne, and more recently recorded from Cockatoo Creek, Victoria, by Johns (1964). The latter author erected the subgenus Australopeltis for this species, restricting the nominate subgenus Pseudoprionopeltis Carl to some New Zealand species. Australopeltis has since been raised to generic rank, and quite correctly so, by Hoffman (1980). As Lissodesmus and Australopeltis cover the same generic concept, the latter name falls as a junior subjective synonym of Lissodesmus.

In addition to the four species collected, a fifth species of Lissodesmus was discovered among material received on loan from the Tasmanian Department of Agriculture.

The holotypes and some paratypes of the new species have been deposited in the Tasmanian Museum and Art Gallery, Hobart. Some paratypes of Lissodesmus margaretae and the remainder of the material under report are preserved in the Zoological Museum at Amsterdam.

\section{CLASSIFICATION OF THE GENERA ASPHALIDESMUS SILVESTRI AND ATOPODESMUS CHAMBERLIN}

Recently the known non-paradoxosomatid Polydesmida of Australia were referred to the family Dalodesmidae, although with some reservation with regard to the status of those genera of which the male characters were not or insufficiently known (Jeeke1 1981). The association of the latter genera with the Dalodesmidae seemed the most logical solution in view of the apparent lack of evidence to the contrary and the probability inferred by the sympatry of the taxa involved.

In his classification of the Diplopoda, Hoffman (1980) referred the Tasmanian genera Asphalidesmus, Lissodesmus and Tasmaniosoma to the Dalodesmidae, assuming a close relationship or even identity of Asphalidesmus and Tasmaniosoma, whereas Atopodesmus was 1isted under the Polydesmidae of uncertain status and family position, and Tasmanodesmus was $1 \mathrm{eft}$ out of consideration.

A careful re-evaluation of the available generic and specific descriptions has now led to the conclusion that these recent concepts were an oversimplification of the actual situation. In fact, there appears to be strong evidence that Asphalidesmus and Atopodesmus should be excluded from the Dalodesmidae.

Although other male characters of Asphazidesmus have been described, it is not known whether the legs have the modified setae characteristic of almost all Dalodesmidae. From the absence in the description of any statement on this particular feature it is inferred that the legs have normal setae.

That Atopodesmus is closely related to Asphalidesmus seems quite obvious, in spite of the absence of information on its male characters. The two taxa share some non-sexual details which at the same time distinguish them quite well from the dalodesmid genera reported from Tasmania. Both genera are characterized by having the paranota of the second somite relatively strongly developed, produced anteriorly and posteriorly and sloping downwards so as to form a collar-1ike structure embracing the head and the first tergite. 
Both genera are represented by smal1 forms of about $6 \mathrm{~mm}$ length, whose metatergites are covered with numerous setiferous granules. The conclusion must be that the two genera are either aberrant Dalodesmidae or should be excluded from that family.

With regard to this question a comparison between the polydesmid faunae of Tasmania and South Africa gives a clarifying hint. South Africa has, besides the Paradoxosomatidae and Gomphodesmidae, the taxonomic status of which is irrelevant to the problem at hand, three polydesmoid groups: the Pyrgodesmidae, the Dalodesmidae and the Vaalogonopodidae. The first of these is represented by a single genus and species. The Dalodesmidae of South Africa has numerous genera and species; the endemic Vaalogonopodidae consists only of a sma11 number of species referred to two closely related genera: Phygoxerotes Verhoeff, 1939, and VaaZogonopus Verhoeff, 1940.

To refer Asphalidesmus to the Pyrgodesmidae is out of the question considering the gonopod structure and other morphological particulars. However, a comparison of the descriptions of Phygoxerotes and Vaalogonopus on the one hand, and of Asphalidesmus and Atopodesmus on the other, reveals a remarkable degree of similarity in general habit and in the gonopods. This, combined with the remarkable. faunistic parallelism of the Polydesmida of South Africa and Tasmania, seems to justify the conclusion that Asphalidesmus and Atopodesmus are referable to the Vaalogonopodidae rather than to the Dalodesmidae.

So far, mystery has surrounded the status of the Vaalogonopodidae within the polydesmid system. When Verhoeff (1939) described Phygoxerotes, he referred the genus to the "Sphaerotrichopidae" (= Dalodesmidae), apparently on negative grounds only. He noted that the genus could not be referred satisfactorily to any of the other South African polydesmid families, but at the same time pointed out a resemblance between the gonopods of Phygoxerotes and certain Gomphodesmidae and Platyrhacidae, and suggested a close relationship between these two families and the "Sphaerotrichopidae".

Verhoeff (1940) described the genus Vaalogonopus and erected for this genus and Phygoxerotes the family "Vaalogonopidae" (= Vaalogonopodidae). The two genera are very closely related indeed, but Vaalogonopus lacks the enlarged paranota of the second somite, and its collum is particularly enlarged. Obviously, it was under the impression of the latter feature that Verhoeff dropped his former opinion on the relationship of Phygoxerotes and associated the Valogonopodidae with other polydesmid groups having an enlarged collum: the Cryptodesmidae (in a wide sence, including the Pyrgodesmidae of Hoffman's classification), the Niponiellidae (now regarded a tribe in the family Cryptodesmidae), and the Macellolophidae (now a tribe in the chelodesmoid family Xystodesmidae according to Hoffman). It is a point of interest to mention here that Verhoeff, quite incidentally, pointed to a certain resemblance in the gonopods of the Vaalogonopodidae and the genus Gonomastis Attems (= HeZodesmus Cook).

Lawrence (1953), commenting on the taxonomic status of Phygoxerotes, but apparently ignorant of Verhoeff's paper on Vaalogonopus, rejected the opinion that the genus is related to the "Sphaerotrichopidae" or the Gomphodesmidae. He pointed out that there are many instances of superficial similarity in the gonopods of genera belonging to quite unrelated families. Lawrence drew attention to a certain overall similarity between Phygoxerotes and Prosopodesmus Silvestri, but otherwise seemed to regard Phygoxerotes as a diminutive type of Platyrhacidae.

Recently, Hoffman (1980) placed the Vaalogonopodidae with the Dalodesmidae into his suborder Dalodesmidea, a taxon equivalent to the suborders Chelodesmidea, Paradoxosomatidea and Polydesmidea.

In the present understanding of the classification of the order Polydesmida the relationship between the Vaalogonopodidae, Platyrhacidae, Gomphodesmidae or "Mace11olophidae" as suggested by Verhoeff and Lawrence, can be ruled out without further comment. In fact, there are only two options to be considered. Either the Vaalogonopodidae, mainly on account of the characters of the gonopods, is to be associated with the Dalodesmidae, or, if a number of external particulars are given preference, it should be related to certain families in the suborder Polydesmidea. 
Actual1y, the first option was followed by Hoffman, who, by assigning only the Vaalogonopodidae and the Dalodesmidae to the suborder Dalodesmidea, laid special emphasis on the relationship between the two families.

However, as was pointed out above in connection with the status of Asphalidesmus and Atopodesmus the strong evidence of the non-gonopod characters of the Vaalogonopodidae opposes such a close association with the Dalodesmidae. The male leg setation, the structure of the second somite and the sculpture of the metatergites, in combination, seem to provide sufficient argument in favour of the second option.

A family in the suborder Polydesmidea of particular importance to the taxonomic position of the Vaalogonopodidae appears to be the Haplodesmidae. This group has been recently reinstated almost simultaneously by Hoffman (1980) and Jeekel (1980), although based on different concepts. Jeekel included only Cylindrodesmus Pocock (with Fijiodesmus Chamberlin as a probable additional synonymy) and, with some reservation, Phlyctodesmus Chamberlin. Hoffman adopted a wider concept and included also Helodesmus Cook (with its synonyms Gonomastis Attems and Porauxus Chamberlin) and Prosopodesmus Silvestri, each representing a different subfamily.

The association of Helodesmus and Prosopodesmus with Cylindrodesmus was a daring step but seems quite correct. Some doubt might be expressed about the necessity to refer each to a separate subfamily. The concept of the Haplodesmidae was apparently mainly based on the agreement of the pertinent genera in the structure of the second somite, and the fact that the gonopod characters did not contradict their association.

For similar reasons it seems quite likely indeed that the Vaalogonopodidae should be combined with the Haplodesmidae at a subfamily level within the latter. It is of historic interest but only of minor importance that the coordination of the two taxa agrees with the gratuitous remarks on the relationship of the South African Vaalogonopodidae and Gonomastis and Prosopodesmus by Verhoeff and Lawrence.

In connection with this discussion the status of another enigmatic polydesmoid genus should be considered. Atopogonus [sic!] Carl, 1926, is based on a single species from New Caledonia, which like the Haplodesmidae is characterized by the collar-like structure of the second somite. Its metatergites are covered by numerous setiferous granules and Carl characterized the general habit as "Cylindrodesmusartig". On the other hand, the gonopods have a peculiar structure and lack the coxal horn. Obviously on this account Carl referred the genus to the Rhachodesmidae. Verhoeff (1941) erected the family Atopogonidae for the genus, but still associated it with the Rhachodesmidae. It is quite clear that Atopogonus has nothing to do with the Rhachodesmidae, and that the loss of the coxal horn in the genus is the result of an entirely independent evolutionary process. Hoffman (1980) quite correctly removed the Atopogonidae from its association with the Rhachodesmidae but had to place the genus and family among those polydesmid taxa with uncertain status.

It seems best that the Atopogonidae, like the Vaalogonopodidae, be a taxon subordinate to the Haplodesmidae.

The following preliminary classification summarizes the above discussion. To avoid a too complex picture and in accordance with Hoffman's classification, the previous family names are given the rank of subfamily. It will be clear that numerous changes in the position of the genera may occur when Hoffman's prediction that "I do not doubt that its [the Haplodesmidae] ranks will be enlarged as material of various poorly-known small polydesmoids is available for study", is substantiated.

Family Haplodesmidae

Subfamily Haplodesminae (Cy Zindrodesmus Pocock)

Subfamily Helodesminae (HeZodesmus Cook)

Subfamily Prosopodesminae (Prosopodesmus Silvestri)

Subfamily Vaalogonopodinae (Vaalogonopus Verhoeff, Phygoxerotes Verhoeff)

Subfamily Atopogoninae (Atopogonus Carl)

Status uncertain: Atopodesmus Chamberlin, Phymatodesmus De Saussure \& Zehntner, Phlyctodesmus Chamberlin. 
Whether or not the genus Rhipidopeltis Miyosi belongs to the Haplodesmidae seems uncertain. Perhaps it would be better to associate this genus with the family Cryptodesmidae.

That the Haplodesmidae have a certain relationship with the Doratodesmidae, as suggested in Hoffman's classification seems quite likely. In fact, one may wonder if not certain genera referred to the Doratodesmidae should not be reallocated in the Haplodesmidae.

\section{KEY TO THE GENERA OF THE ORDER POLYDESMIDA REPORTED FROM TASMANIA}

(EXCLUDING INTRODUCED EUROPEAN SPECIES)

la Coxae of gonopods free, not coalesced medially; the gonopod aperture medially more or less constricted. Legs of male generally with tibial and tarsal scopulae, the basal podomeres without modified setae. Paranota with swollen lateral margins, which are dorsally demarcated by a furrow and ventrally by a depression. The pores situated on the lateral surface of the paranota. When paranota are absent the pores open on the lateral side of the metatergites and are not accompanied by furrows. Metatergites usually hairless, generally with a transverse furrow, but without other sculpture. (Paradoxosomatidae) ..... Notodesmus Chamberlin

lb Coxae of gonopods medially solidly connected; the gonopod aperture elliptical, oval or heart-shaped, not medially constricted. Legs of male without scopulae, either with unmodified setae or with all podomeres with short, dense setation of modified setae. Paranota without swollen lateral margins, only dorsally demarcated by a premarginal furrow. Pore situated on the laterodorsal side, in or near the premarginal furrow. Metatergites either without transverse furrow or sculpture, or with areas demarcated by furrows, or densely covered by setiferous granules.

2a Second somite much wider than collum; its paranota anteriorly and posteriorly expanded, directed downward so as to more or less embrace the head and collum like a collar. Metatergites with numerous small setiferous granules. Legs of male without modified setae. Small species of about $6 \mathrm{~mm}$ length. (Haplodesmidae)

$$
\text { ..... Asphalidesmus Silvestri }
$$

$2 \mathrm{~b}$ Second somite not much wider than collum; its paranota not differing essentially from those of the next somites. Metatergites either smooth and without scuplture or with a transverse furrow and a number of inflated areas marked by sulci. Legs of male ventrally with a dense setation of short stiff bristles and spherical bristles. Larger species of over $10 \mathrm{~mm}$ length. (Dalodesmidae)

3a Somites cylindrical, weakly constricted in the waist area. Paranota reduced, ridgelike

....... Gasterograma Jeekel

3b Somites with well developed paranota. Metatergites dorsally more or less flattened

4a Nineteen somites. Metatergites with a transverse furrow and with 4 to 6 weakly demarcated areas in front

...... Tasmoniosoma Verhoeff

4 b Twenty somites. Metatergites without transverse furrow or demarcated areas .... 5

5 a Metatergites with three transverse rows of setae. Each tarsus exceeding each other podomere in length, widely curved. ..... Tasmanodesmus Chamberlin

5 b Metatergites without transverse rows of setae, only with a long hair mesad of caudal edge of paranota. Each tarsus not (much) longer than femur, not curved.

\section{LISSODESMUS CHAMBERLIN}

Lissodesmus Chamberlin, 1920 , p.135.

Australopeltis (as subgenus of Pseudoprionopeltis Carl, 1902) Johns 1964, p.47; (as genus) Hoffman, 1980 , p.184.

Type-species

Lissodesmus modestus Chamberlin, 1920 (type-species of Australopeltis:

Pseudoprionopeltis martini Car1, 1902). 
To this monotypic genus are now added four new vicariant species from Tasmania, and Lissodesmus martini (Car1) from Victoria.

As in many dalodesmid genera, the gonopods in Lissodesmus are of a highly modified type in comparison with the more primitive gonopods found in certain paradoxosomatid genera. There are no indications of an articular subdivision in the telopodite and the location and size of the various branches deviate greatly from the presumed precursor.

In essence, the telopodite of the gonopods in Lissodesmus gives rise to four separate elements, one of which contains the spermal channel and must be regarded as the solenomerite. This is a relatively small, spine-like process, apically acuminate and generally bearing one or two minute preapical lappets. Its base is situated about halfway the total length of the telopodite or a little more proximally, either on the medio- or the lateroanterior side.

Mediocaudad of the solenomerite base there arises a small spine, or truncate spine or lanceolate process, which, consistent with the morphological interpretation of the paradoxosomatid gonopods (cf. Jeekel 1968, p.21, fig.1), is considered to be the homologue of the tibiotarsus.

A third process, bifurcate in the newly described Tasmanian species but unbranched in L. modestus and L. martini, arises laterocaudad of the solenomerite base, and for that reason may be considered to be a process either of the femur or postfemur of the telopodite.

The main body of the telopodite is, however, formed by a strongly elongate prefemur, the homology being substantiated by the fact that at least in L. adrianae n.sp. its caudal surface is continuously setiferous up to near the apex and that it does not show any discontinuity in its chitinous structure.

According to the above homologization, it is concluded that the femur and postfemur of the gonopods in Lissodesmus are vestigial and have merged into the prefemur. A similar situation has been described for Gasterogramma Jeekel (1982, p.10). The latter genus is moreover characterized by a strong torsion of the telopodite.

In conformity with the original diagnosis of the genus all species treated here have a body of a head and 20 somites. The poreformula is usually normal, but one new species, L. perporosus, has an abnormal formula: 5, 7, 9-19. This condition would formerly have been considered sufficient basis for a separate genus. But the great similarity in the gonopod structure of this species and the other Tasmanian species devaluates this character to the level of specific importance only.

In the polydesmid fauna of Tasmania the representatives of the genus are easily distinguished by their pallid colour, smooth metatergites and lack of any furrows or granulation, one long hair arising from the caudal border of the paranota just mesad of the laterocaudal edge, and the typical structure of the gonopods.

Key to the Species of Lissodesmus

la Posterior margin of paranota with about three triangular teeth. Gonopods in situ reaching to just in front of the 6th sternite. Femoral process of gonopods unbranched, not reaching the apex of the prefemur, its apex acuminate, entire. Prefemur with a single median uncate process. Width of male $2.0 \mathrm{~mm}$ (Victoria).

...... L. martini (Car 1$)$

lb Posterior margin of paranota without teeth. Femoral process of gonopods bifurcate and not reaching the apex of the prefemur, or unbranched and reaching as far as the apex of the prefemur. (Tasmania)

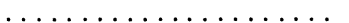

2a Gonopods in situ reaching the anterior margin of the 5 th sternite. Femoral process reaching as far as the apex of the prefemur, unbranched, its apex subspatulate, serrulate. Prefemur without medial uncus. Paranota with 
distinctly notched lateral margins and acutely angular, well produced caudal edges. Width of male $2.0-2.3 \mathrm{~mm}$ ....... L. modestus Chamberlin

$2 \mathrm{~b}$ Gonopods in situ scarcely surpassing the anterior margin of the 6 th sternite. Femoral process bifurcate. Lateral margins of paranota weakly

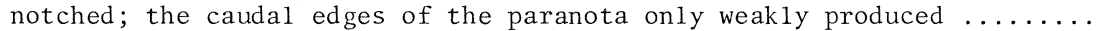

3a Pores on somites, 5, 7, 9-19. Tibiotarsus, solenomerite and femoral process arising well proximad of half the length of the telopodite of the gonopods. Prefemur with four medial unci. Width of male 2.4-2.7 mm Tibiotarsus, solenomerite and femoral process arising from about the middle, or a little distad of the middle of the length of the telopodite of the gonopods $\ldots \ldots \ldots \ldots \ldots \ldots \ldots \ldots \ldots \ldots$

$4 \mathrm{a}$ Femoral process arising well distad of the base of the tibiotarsus, one of its branches finely fringed. Anterior side of prefemur, proximad of base of solenoperite, convex. Prefemur with two preapical unci. Width of male 1.7-2.0 mm.

...... L. margaretae n.sp.

$4 \mathrm{~b}$ Femoral process and tibiotarsus arising from about the same level. Anterior side of prefemur straight. Both branches of the femoral process simply acuminate.

5 a Branches of femoral process of the gonopods of subequal length. Tibiotarsus spiniform, acuminate. Prefemur setiferous up to half its length its distal part bearing one medial uncus. Width of male 1.7-2.0 mm

$5 \mathrm{~b}$ Branches of femoral process quite unequal in length. Tibiotarsus ....... L. alisonae n. sp. truncate. Prefemur setiferous up to near the apex, serrulate, without unci. Width of male $2.5-2.8 \mathrm{~mm}$. ...... L. adrianae n. sp.

\section{Lissodesmus modestus Chamberlin}

Lissodesmus modestus Chamberlin, 1920, p.135.

Previous record

Russel1 Fal1s, Tasmania.

Material

Sta.105. Mt Field National Park, $4 \mathrm{~km}$ W National Park, $9 \mathrm{~km}$ NNE Maydena, 27.XI.1980 [upper zone of temperate rainforest (Nothofagus, Eucalyptus, Dicksonia) along nature track, very wet soil, under logs], 1 б', 4 juv. $q$ (18 somites).

Sta.108. Mt Wellington, $7 \mathrm{~km}$ SW Hobart, 28.XI.1980 [wet sclerophyllous forest with some ferntrees, under logs, stones and litter], $2 \sigma^{\pi}, 1$, 1 juv. $\sigma^{\top}$ (19 somites), 1 juv. $q$ (19 somites).

Description

Colour.- Pale orange brown, the head and tergites with a fine network of reddish brown, the darker pigment concentrated particularly in a narrow zone along the posterior margin of the tergites. Venter, sternites and legs pale pinkish yellow.

Width.- $\sigma: 2.0-2.3 \mathrm{~mm}, q ; 2.4 \mathrm{~mm}$, juv. $\sigma^{*}(19 \mathrm{~s}):. 2.1 \mathrm{~mm}$, juv. $q(19 \mathrm{~s}):. 2.2 \mathrm{~mm}$, juv. જ̛ (18 s.) : $1.4-1.5 \mathrm{~mm}$.

Head and antennae.- Labrum rather widely and moderately deeply emarginate. Clypeus rather convex, smooth, well impressed towards the labrum. The lateral border straight, without a notch near the labrum. Pubescence moderately dense up to the middle of the vertex, and on the lateral parts of the head. The setae partly long; some hairs on the vertex quite long. Antennal sockets not impressed, separated from each other by two times the diameter of a socket or by 0.9 times the length of the 2 nd antennomere. Postantennal groove wide and rather deep, the wall in front moderately prominent. Vertex smooth and shiny, transversely weakly and evenly convex, longitudinally rather convex, particularly in the upper half. Vertigial sulcus weakly impressed, disappearing well above the upper level of the antennal sockets. Antennae of moderate length, moderately stout, a little clavate, 
with the 6 th antennomere thickest. Antennomeres 2 and 3 subcylindrical, widening distad, the 4 th and 5 th obconical, the 6 th subcylindrical, a little inflated. Relative length of antennomeres 2 to $6: 1.00,0.90,0.65,0.65,0.85$ ( 6 th to 8 th inclusive: 1.20). Pubescence moderate in proximal antennomeres, becoming dense in the distal ones.

Collum.- A little wider than the head, subtrapezoidal in dorsal outline. Anterior margin straight or faintly convex in the middle, laterally rather strongly rounded, and straight again towards the lateral edge. Posterior margin weakly concave in the middle, laterally widely rounded and straight again towards the edge. Lateral margin with two weak indentations (both sometimes bearing a rather long seta); the posterior edge subangular, wide, very narrowly rounded and not produced caudad. Surface smooth, with a transverse row of rather long setae along the anterior margin. A long hair also near the posterior margin, rather close to the lateral edge. Surface transversely and longitudinally widely and evenly convex. Lateral margin with a fine rim, the premarginal furrow sharply impressed, disappearing near the lateral edge of the vertex.

Somites.- Constriction rather weak. Waist broad, sharply demarcated from the prosomites, not distinctly demarcated from the metatergites, the transition to metatergites finely longitudinally striate. Prosomites a little dullish. Surface of metatergites more shiny, hairless except for a long seta quite near the concave posterior margin of the paranota. No transverse furrow or other sculpture, at most a vague transverse depression. Sides somewhat rugulose or subgranulose. No pleural keels.

Paranota. - Second somite somewhat wider than the collum; the 3rd scarcely wider than the $2 \mathrm{nd}$, and the 4 th more distinctly wider than the $3 \mathrm{rd}$. Paranota of 2 nd somite in dorsal aspect with the anterior margin a little shouldered at base, otherwise widely convex. The latero-anterior edge widely subangular, narrowly rounded, with a small but distinct 1 ateral tooth bearing a long hair. Lateral margin widely and almost evenly rounded, with three abortive teeth. Posterior border widely concave; the lateroposterior edge angular, about $90^{\circ}$ and scarcely produced caudad. In lateral aspect the paranota are scarcely sloping cephalad, with the upper margin widely and evenly concave. Marginal rim laterally slightly incrassate, sharply demarcated dorsally by a premarginal furrow running anteriorly to the waist and disappearing caudally near the posterior edge. Posterior margin with a sharp furrow from near the edge to the base of the paranotum. Paranota of 3rd somite similar to those of the 2nd. The lateroanterior edge not angular and without tooth, the anterior border merging into the lateral by a narrow rounding. Lateral border more weakly convex than in the 2nd somite, with three teeth, the anterior of which generally bears a 1 ong hair; the teeth more distinct than in the 2nd somite. Posterior edge more acutely angular than in the 2nd somite, pointed and produced a little caudad. Posterior border less widely concave than in the 2 nd somite. Paranota of 4 th somite similar to those of the 3 rd, but the lateral border scarcely convex, almost straight. The lateroposterior edge more acuminate, and more produced caudad than in the 3rd somite, acutely angular. Posterior margin becoming more concave near lateral edge. Paranota of 3 rd and 4 th somites sloping a little cephalad in lateral aspect, and gradually less laterad from the 2nd to the 4 th somite. Paranota of 5 th and subsequent somites (fig. 1) with anterior margin shoulder a little at base up to the 18 th somite, rather widely rounded and merging into the lateral margin which is almost straight and diverging a little in caudal direction. Four distinct, but not deeply incised lateral teeth, the first generally with a long hair. Posterior edges becoming more and more acute; acuminate and pointed especially in the posterior half of the body. Posterior margin concave, especially at the base. Upper surface of paranota slightly swollen. Pore formula normal, the pore small and inconspicuous, situated near the margin just behind the last lateral tooth, facing laterad, caudad and a little dorsad, just at the base of a weak and small swelling. Marginal rims distinct, the premarginal furrow disappearing at waist and near posterior edge, in poriferous somites just behind the pore. Premarginal furrow along posterior border disappearing near posterior edge near the seta, and at base of paranotum. The marginal rim a little thicker than in the other Tasmanian species. In lateral aspect the upper demarcation of the paranota is faintly concave, turning abruptly upwards anteriorly.

Sternites and legs.- Sternites of middle somites longer than wide (ratio 1.7:1.0). Cross impressions well developed, rather deep and furrow-1ike. Pubescence dense, but setae 
short and not visible at low magnification. Sternite of 4 th somite moderately wide, with a deep median furrow. Sternite of 5 th somite with a deep median furrow between the anterior coxae, deeply and widely excavate between the posterior coxae. Sternite of 6 th somite with a wide and deep excavation, the transverse impression distinct only between the subsequent coxal sockets. Sternite of 7 th somite with a broad oval gonopod aperture, the margin caudally and especially laterally a little raised; the posterior part with a median furrow. Sternite of 8 th somite not modified. Legs rather long, strongly incrassate, especially prefemur and femur. The prefemora dorsally globose, the femora dorsally convex, ventrally straight. Pubescence ventrally very dense, with stiff, short, crooked setae up to the postfemur, and globular setae on tibia and tarsus. Dorsal pubescence moderate in tarsus, sparse in tibia and postfemur, not visible at low magnification in the more basal podomeres. The setae rather short and straight. Legs of first and second pairs not particularly incrassate and relatively short. Coxa of 2 nd legs medially widened and with a small distal cone tipped with some setae of moderate length. Relative length of podomeres 2 to 6 : $0.90,1.00,0.45,0.40,1.00$; the claw rather long.

Anal somite.- Dorsal profile weakly convex. Sides of epiproct concavely converging, nearly parallel towards the apex. Epiproct rather narrow, moderately thick dorsoventrally and rather long; the apex narrowly emarginate, with two short paramedian cones. Anal ring moderately setiferous with conspicuous long setae on minute granules. Paraprocts with rather wide and moderately high marginal rims; the setae not on granules. Hypoproct subtriangular, with sides concave at base, the apex rounded; setae not on granules.

Gonopods (figs 2-3).- Coxa broad at

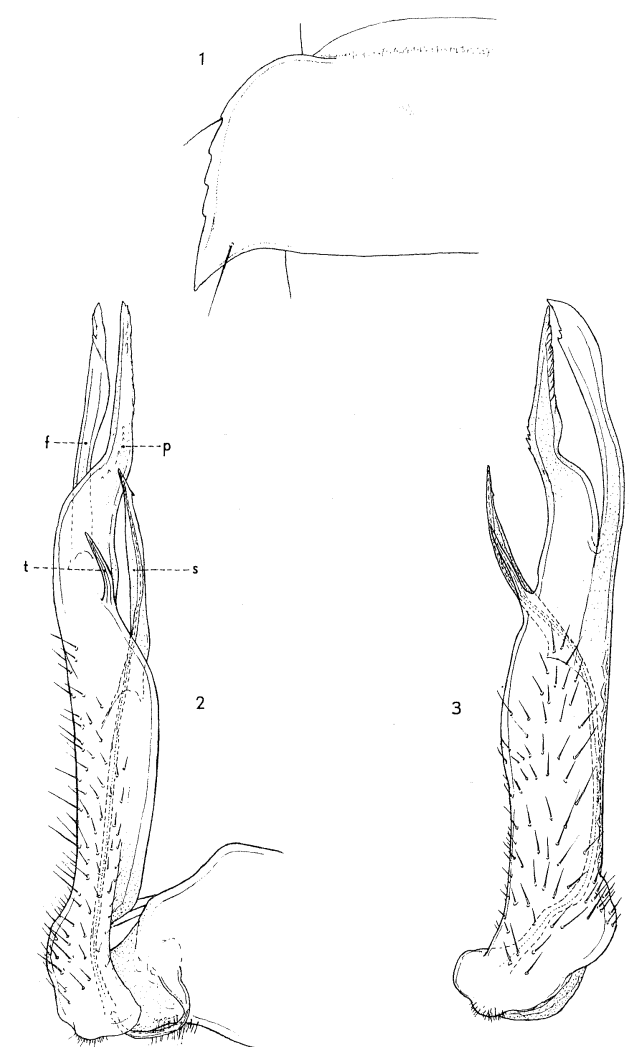

FIGS 1-3 Lissodesmus modestus Chamberl in, 1920, $\sigma^{7}$ from Sta.108. 1 - left side of 11 th somite, dorsal aspect. 2 - right gonopod, medial aspect. 3 - telopodite of left gonopod, caudal aspect. [f - femoral process; p - prefemoral process; s - solenomerite; t - tibiotarsus]. base and solidly connected with the coxa of the opposite gonopod. Its distal part narrowing, with a few long setae on the anterior side, and an area with short setae on the caudal side. Telopodite very long, in situ reaching the anterior margin of the sternite of the 5 th somite. Prefemur setiferous up to about half the length of the telopodite, distally produced into a slender process which shows a slight crook towards the apex. Apex itself with serrate margins, tapering. Solenomerite arising just proximad of half the length of the telopodite, reaching to threequarters of that length. Tibiotarsus arising from the medial side of the telopodite, short, spiniform. Femoral process arising from the lateral side of the telopodite at about two-thirds of the length of the telopodite, slender in most of its length and distally widening a little. The femoral process reaches as far distad as the prefemur.

Female.- A little more robust than the male, but otherwise quite similar. Antennal sockets separated by 2.5 times the diameter of a socket or by 0.9 times the length of the 
2nd antennomere. Relative length of antennomeres 2 to $6: 1.00,0.80,0.60,0.65,0.85$ (6th to 8 th inclusive: 1.20). Sides of somites up to about the 4 th a little granulose.

Sternites longer than wide (ratio $1.35: 1.00$ ). The pubescence of the sternites rather dense, with setae of moderate length. Legs a little shorter than in the male and not incrassate. The prefemur thick and dorsally widely convex, the femur much narrower than in the male. Relative length of podomeres 2 to $6: 1.00,1.00,0.40,0.40,0.90$. Ventral pubescence of podomeres rather dense, with setae of moderate length. The typical modified setation of the male is lacking. Upper side of podomeres sparsely setiferous, moderately in tibiae and tarsi. Epigynal structure consisting of a transverse plate, directed ventrad and shielding the coxae of the 2 nd pair of legs from behind. The plate is broadly triangular, with a wide median narrowly rounded edge, the sides widely and weakly emarginate, with laterally a small slight elevation. Coxae of 2 nd legs broad, their caudal side with a small, slightly swollen subquadrate process projecting caudad.

Remarks

Lissodesmus modestus is distinguished from all other known species of the genus by the remarkable length of the telopodite of the gonopod, which, in situ, reaches as far as the anterior border of the sternite of the 5th somite. Also characteristic are the length of the femoral process, which reaches as far distal as the apex of the prefemur, the distinct teeth of the lateral margin and pronounced posterior edges of the paranota.

L. modestus differs from the Tasmanian species in that the femoral process is unbranched; a character shared with the Victorian L. martini (Carl).

In his description Chamberlin stated that the 2nd and 6th antennomeres are the longest with which present observations do not agree. It seems possible that Chamberlin actually meant the length of the 2nd and 6th to 8 th antennomeres. Otherwise, considering the fact that the material from Sta.105 is almost topotypical and that Chamberlin's description of the genus and species matches the specimens at hand in other details, there can be hardly any doubt about the correctness of the identification.

\section{Lissodesmus adrianae n.sp.}

Material

Sta.96. Ben Lomond National Park, 35 km ENE Evandale, 23.XI.1980 [along the road to the top of Ben Lomond, near the park ranger office, wet sclerophyllous forest with dense undergrowth of shrubs, under logs, litter and in humus]. o holotype, $9 \sigma^{\pi}, 19$ o, 10 juv. $\sigma^{\prime \prime}$ (19 somites), 9 juv. o (19 somites), 2 juv. $q$ (18 somites) paratypes.

Sta.97. $10 \mathrm{~km} \mathrm{NE} \mathrm{Blessington,} 28 \mathrm{~km}$ ENE Evandale, 23.XI.1980 [dry type Eucalyptus forest in grassland, under logs]. 1 o paratype.

Description

Colour.- In general greyish orange brown, the venter, sternites and legs somewhat paler.

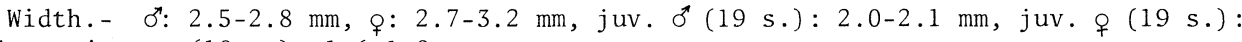
$2.0-2.4 \mathrm{~mm}$, juv. o (18 s.) : $1.6-1.8 \mathrm{~mm}$.

Head and antennae.- Labrum weakly and moderately widely emarginate. Clypeus strongly impressed towards the labrum; its lateral border a little emarginate near the labrum. Pubescence of headplate becoming rather sparse in the frontal region and in the lower part of the vertex. Antennal sockets somewhat impressed. Postantennal groove wide and shallow, the wall in front very weakly prominent. Vertex longitudinally rather strong$1 \mathrm{y}$ and evenly convex. Antennae shortish and moderately stout, distinctly clavate, with the antennomeres 2 to 6 each a little wider than the preceding. Relative length of antennomeres 2 to $6: 1.00,0.85,0.60,0.60,0.65$ (6th to 8 th inclusive: 0.90 ).

Collum.- Lateral margin widely rounded, with three weak indentations, and caudally subangular, narrowly rounded. Surface with, besides the series of long setae along the anterior margin, some more setae just in front of the middle.

Somites.- Sides smooth. 
Paranota. - Second and 3rd somites each a little wider than the preceding somite, the 4 th scarcely wider than the $3 \mathrm{rd}$. Paranota of 2 nd somite in dorsal aspect with the anterior margin shouldered, but otherwise straight. Lateral margin a little more convex towards the lateroposterior edge, with three minor or partly abortive teeth. Posterior border faintly concave. The lateroposterior edge widely angular. In lateral aspect the upper margin of the paranota is straight or faintly concave, concavity upwards, and more strongly concave near caudal edge. Marginal rim thin and narrow. Paranota of 3 rd somite with the anterior border rounded, the lateroanterior edge less pronounced than in the 2 nd somite. Paranota of 4 th somite similar, but without lateroanterior edge, the anterior margin merging into the lateral margin. Paranota of 5 th and subsequent somites (fig. 4) with the anterior margin shouldered at base ex-

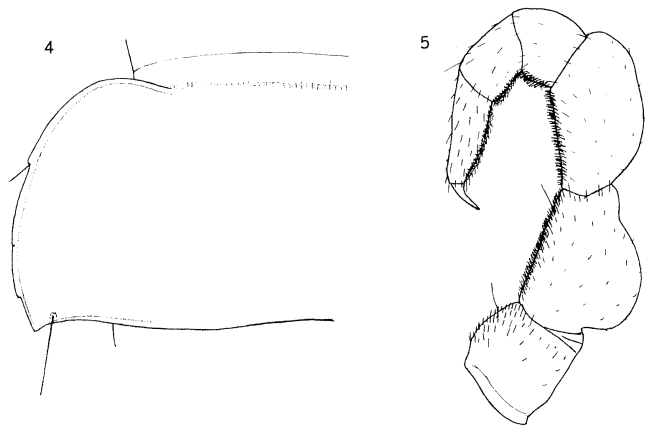
cept in the 17 th to 19 th somites. Lateral margin widely and almost evenly convex, diverging slightly caudad, curving mesad a little towards the caudal edge. Margin with three or four weak teeth, of which the first and last are the most distinct, the first often bearing a rather long hair. Poriferous somites with the lateral margin a little more strongly incurved from the pore area onwards. Posterior edges about rectangular, pointed, becoming more acuminate in the second half of the body. Pores situated near the caudal edge, just a little behind the second lateral marginal tooth. Pores facing laterad, dorsad and a little caudad. In lateral aspect the dorsal demarcation of the paranota is faintly concave, more so near the caudal edge, and particularly in the poriferous somites curving rather strongly upward near the pore.

Sternites and legs.- Sternites of middle somites longer than wide (ratio 1.3:1.0). Cross impressions medially and transversely with a fine central furrow. Sternite of 5 th somite lacking the modifications of the previous species. Legs (fig. 5) with the femora ventrally quite faintly arched. Coxae of 2 nd pair medially produced into a low rounded cone bearing an apical tuft of setae. Relative length of podomeres 2 to $6: 0.90,1.00$, $0.50,0.45,0.75$.

Anal somite.- Upper profile straight or faintly convex. Epiproct moderately wide. Sides of epiproct not nearly parallel towards the apex. Apex with a pair of rather long and slender terminal cones, with a deep emargination in between. Hypoproct rather long, narrowly trapezoidal, with the sides straight at base and faintly convex distally; the posterior margin almost semicircularly rounded.

Gonopods (figs 6-7).- Telopodite in situ just reaching the posterior coxae of the 5 th somite. Prefemur setiferous up to near the apex of the telopodite; the apex of the prefemoral process truncate-serrulate, medial margin also serrulate. Solenomerite arising about halfway the length of the telopodite, and reaching to about two-thirds of length. Tibiotarsus short, distally truncate, arising a little distad of base of solenomerite. Femoral process arising from about the same level as the tibiotarsus or solenomerite, bifurcate; the posterior branch short, pointing caudad and a little distad; the distal branch longer, reaching to about three-quarters of the length of the telopodite.

Female.- Antennal sockets separated by 2.25 times the diameter of a socket or by 1.2 times the length of the 2nd antennomere. Relative length of antennomeres 2 to 6: 1.00, $0.80,0.70,0.60,0.75$ (6th to 8 th inclusive: 1.00 ). Sternites longer than wide (ratio $1.2: 1.0)$. Relative length of podomeres 2 to $6: 1.00,0.90,0.40,0.40,0.75$. The epigynal structure with the plate a little lower than in the previous species, the lateral edges laterad of emarginations not apparent. Coxae of 2 nd pair of legs broad, but without posterior projection. 

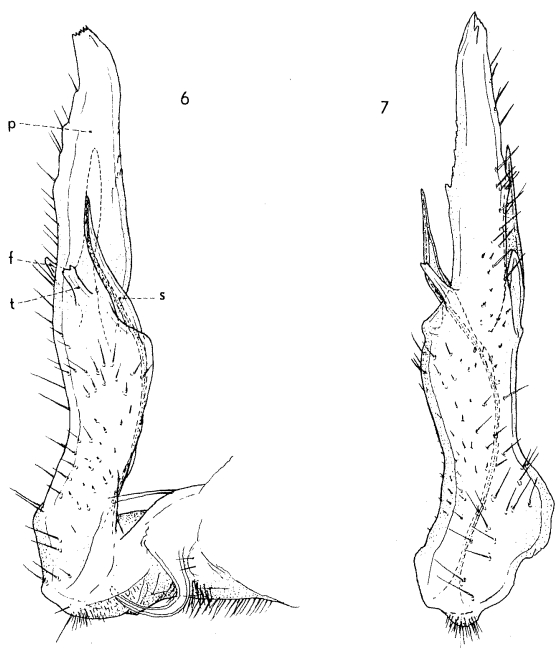

FIGS 6-7 Lissodesmus adrianae n.sp.

$\sigma^{7}$ holotype. 6 - right gonopod, medial aspect. 7 - telopodite of left gonopod, caudal aspect. Lettering as in figs $1-3$.

Remarks

In the points not mentioned the description of $L$. modestus applies.

L. adrianae n.sp. approaches $L$. perporosus n.sp. in its relatively large size and also in the outline of the paranota. It is easily distinguished by the normal poreformula and the structure of the gonopods .

The species is dedicated to Mrs Adriana M. Jeekel-Rijvers, who actively participated in obtaining the type material.

\section{Lissodesmus alisonae n.sp.}

\section{Material}

Sta.99. $8 \mathrm{~km} \mathrm{NW}$ Frankford, $15 \mathrm{~km} \mathrm{SW}$ Beaconsfield, 24.XI.1980 [open Eucalyptus forest with grassland, rather wet, under logs and in soil]. of holotype, 12 o , 21 , 1 juv. ó (19 somites), 1 juv. \& (18 somites) paratypes.

Description

Colour.- In general light orange brown. Head with frons and lower part of vertex reddish brown, areolated with the

lighter colour. Antennae with the distal part of the $4 \mathrm{th}$, and the entire $5 \mathrm{th}, 6 \mathrm{th}$ and $7 \mathrm{th}$ antennomeres reddish brown. The anterior, lateral and posterior margins of the collum, and the posterior margin of the metatergites, broadest medially, also reddish brown, areolated with light colour. Venter, sternites and legs and anal somites light orange brown.

mm.

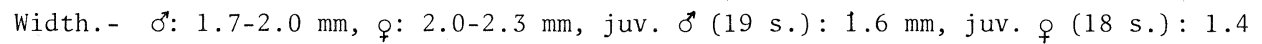

Head and antennae.- Clypeus with minute wrinkles; its lateral border straight, weakly emarginate towards the labrum. Antennal sockets a little impressed at the oral side; separated in 2.1 times the diameter of a socket or by the length of the 2 nd antennomere. The 6 th antennomere subcylindrical, with sides a little convex, the base constricted. Relative length of antennomeres 2 to $6: 0.95,0.95,0.75,0.75,1.00$ (6th to 8 th inclusive: 1.20).

Collum.- Scarcely wider than the head. The anterior border almost straight in the middle, gradually more convex towards the lateral side, the lateral border almost evenly convex, scarcely undulate. Posterior border emarginate in the middle, straight more laterally and faintly convex near lateroposterior edge. The lateroposterior edge about rectangular, narrowly rounded, not produced caudad. Behind the series of setae along the anterior margin a few long setae; the long hair near the posterior margin somewhat remote from the lateroposterior edge. Premarginal furrow along the lateral border continuous with the furrow along the posterior margin.

Paranota. - Fourth somite a little wider than the 3rd. Paranota of 2nd somite with the anterior edge subangular, rather narrowly rounded and with a small but distinct tooth. Lateral border with three teeth, of which the anterior is distinct and the posterior almost abortive. Posterior border faintly concave. The lateroposterior edge a little over $90^{\circ}$, acuminately angular, not produced caudad. Marginal rim thin, the premarginal furrow of lateral border merging into that of the posterior border. In lateral aspect the paranota are sloping a little cephalad. Paranota of 3 rd somite with the lateral border a little more convex than in the 2 nd somite. Lateroanterior tooth small and indistinct, the 1 ateral 
two or three teeth similar to those of 2nd somite. Posterior border distinctly emarginate near the lateroposterior edge which is acutely angular, pointed and a little produced caudad. Paranota of 4 th somite with the lateroanterior edge more widely rounded, merging into the lateral border. The lateral border a little more widely convex than in the $3 \mathrm{rd}$ somite, with three teeth which are weaker than in the 3rd somite, the anterior one bearing a hair. Posterior border more distinctly emarginate near lateral edge; the edge more acuminate and a little more produced caudad. Paranota of 5 th and subsequent somites (fig. 8) shouldered a little at anterior base, though scarcely or not in the paranota of the second half of the body. Anterior and lateral borders widely rounded, the lateral border a little less convex, in general diverging a little caudad up to near the pore and behind the pore curving a little inwards. Lateral border without teeth; only in the 5 th and a few subsequent somites a weakly indicated tooth with a seta. Posterior margin rather concave near the lateroposterior edge. Lateroposterior edge acute, finely pointed, a little produced caudad, projecting slightly caudad of posterior margin of somite in the caudal half of the body. Marginal rim narrow, present on all margins of the paranota. Pores facing laterad and a little caudad, scarcely dorsad. In lateral aspect the dorsal margin of the paranota is widely concave, concavity upwards, turning a little more strongly upwards near the posterior edge.

Sternites and legs.- Sternites of middle somites longer than wide (ratio $(1.5: 1.0)$. Sternite of 4 th somite with a moderately deep median furrow. Sternite of 7 th somite with posterior part widely concave. Legs with the femora faintly arched; the tibiae ventrally a little inflated towards the apex. Relative length of podomeres 2 to $6: 0.80,1.00,0.40,0.50,0.85$.

Anal somite.- Hypoproct truncate triangular; the apex rather widely rounded; the setae on weak tubercles forming the edges of the posterior margin.

Gonopods (figs 9-10).- Telopodite in situ reaching to just in front of the 6th sternite. Prefemur hairless in the distal two-fifths of its length, bearing only a single uncus at about three-quarters of length; the apex finely denticulate, curving a little mesocaudad. Solenomerite arising just distad of middle of length of telopodite, reaching to about threequarters of length. Tibiotarsus a little shorter than the solenomerite, slender, straight, apically acuminate, arising just proximad of base of solenomerite. Femoral process arising from about the same level as the solenomerite, its anterior branch longer than its distal branch. The anterior branch curving distad and even a little cephalad.

Female.- Antennal sockets separated by 2.1 times the diameter of a socket or by 0.95 times the length of the 2nd antennomere. Relative length of antennomeres 2 to 6: 0.95 , $0.80,0.65,0.60,1.00$ (6th to 8 th inclusive: 1.20). Sternites 1.35 times longer than wide. Relative length of podomeres 2 to $6: 1.00,0.95,0.35,0.40,0.95$. Epigyne with the triangular plate without distinct lateral edges. The coxae of the 2nd pair of legs medially extended, contiguous at base, obliquely truncate in distal half, without processes.

Remarks

In the points not mentioned the description of Lissodesmus modestus applies.

Together with L. margaretae n.sp. this is the smallest species of the genus. It is we11 characterized by the structure of the gonopods. In the paranota the wide curve of the anterior and lateral borders and the absence of distinct lateral teeth is characteristic. 
The species is kindly dedicated to Miss Alison J.A. Green, the diligent Curator of Invertebrate Zoology at the Tasmanian Museum and Art Gallery.

Lissodesmus perporosus n.sp.

Material

Sta.100. Hellyer Gorge, $32 \mathrm{~km} \mathrm{SSW} \mathrm{Somerset,} \mathrm{25.XI.1980} \mathrm{[temperate} \mathrm{rainforest}$ (Nothofagus, Eucalyptus, Dicksonia) along the Hellyer River, under logs], $\delta^{*}$ holotype, $6 \delta^{*}$, 13 \&, 3 juv. o' (19 somites), 2 juv. $q$ (19 somites) paratypes.

Sta.103. $12 \mathrm{~km}$ SW Derwent Bridge, 26.XI.1980 [open, recently burned Eucalyptus forest, rather wet, under logs], 1 of paratype.

Sta.104. Lake St Clair National Park, near Cynthia Bay, $5 \mathrm{~km}$ WNW Derwent Bridge [wet Eucalyptus forest, under logs], 2 ơ, 4 \& paratypes.

Description

Colour.- In general similar to that of the preceding species. There is a fine network of reddish brown pigment, concentrated in particular along the anterior and 1 ateral borders of the collum, along the posterior margin of the metatergites and on each laterodorsal side of the free part of the prosomites.

Width. - of: 2.4-2.7 mm, o: 2.9-3.3 mm, juv. of (19 s.): 2.1-2.2 mm, juv. o (19 s.): 2.2-2.3 mm. The material from Sta.100 is slightly larger in width than that of the two other stations.

Head and antennae.- Lateral border of clypeus faintly convex, weakly emarginate near the labrum. Clypeus finely rugulose. Antennal sockets anteriorly a little impressed, separated by 2.2 times the diameter of a socket or by the length of the 2 nd antennomere. Relative length of antennomeres 2 to $6: 1.00,1.00,0.65,0.65,0.85$ (6th to 8 th inclusive: $1.10)$.

Collum.- Anterior border faintly convex, gradually a little more convex towards the sides; the lateral border weakly convex with three weak undulations. Posterior margin well emarginate in the middle, widely rounded more laterally, and straight or faintly concave towards the lateroposterior edge. Lateroposterior edge subangular, about $90^{\circ}$, narrowly rounded. Surface with behind the series of setae along the anterior margin a few long hairs. Marginal rim along the lateral border narrow; no premarginal furrow along the posterior margin.

Paranota.- Lateral margin in 2nd somite with three rather distinct teeth. Posterior margin faintly emarginate towards the lateroposterior edge, almost straight. The edge angular, a little wider than $90^{\circ}$, not or scarcely produced. Marginal rim along the lateral border narrow; no premarginal furrow along the posterior border. Paranota of $3 \mathrm{rd}$ somite with the lateroanterior edge marked by a minute tooth. The lateral margin with three rather distinct teeth, the anterior one bearing a hair. Lateral margin a little more convex than in the 2nd somite. Posterior margin a little more concave, especially near the posterior edge which is acuminately angular and about $90^{\circ}$. Paranota of 4 th somite with the lateral margin as convex as in the $3 \mathrm{rd}$ somite. The posterior edge scarcely more defined than in the 3 rd somite, slightly more produced caudad. Paranota of 5 th and subsequent somites (fig. 11) shouldered a little at the anterior base up to the middle of the body. Anterior margin weakly rounded, becoming more convex laterally where it merges into the widely convex lateral margin. Lateral margin scarcely diverging caudad, posteriorly incurved behind the pore area. Lateral margin with four small but rather distinct teeth, the first of which generally bears a long hair. Posterior margin concave at base of paranota, then weakly convex and finally rather concave near the lateroposterior edge. Lateroposterior edge acutely angular, pointed, produced, especially in posterior half of body and projecting a little behind the margin of the somite in the posterior somites. Marginal rim narrow, no premarginal furrow along the caudal border. Poreformula abnormal: 5, 7, 9-19. The pores situated a little behind the third tooth. Pores facing laterad and caudad and a little dorsad. 
Sternites and legs.- Sternites of middle somites longer than wide (ratio $1.2: 1.0$ ). Sternite of 7 th somite in the posterior part rather widely medially excavate. Tibiae with a ventrodistal swelling. Relative length of podomeres 2 to $6: 0.90,1.00,0.45$, $0.40,0.95$.

Anal somite.- Hypoproct truncate triangular; the apex faintly convex, the setae on the edges of apex.

Gonopods (figs 12-13).- In situ, reaching almost to the posterior margin of the 5th sternite. Distal half of prefemur without setae. The prefemur with two small unci on the medial side at about two-thirds of length and three more near the apex, which is bifid and curving caudad and a little mesad. Solenomerite arising at about two-fifth of length of telopodite, reaching to about three-fifths of length. Tibiotarsus arising mesad of basis of solenomerite at about the same level, rather strongly developed, somewhat sigmoidally curved, apically acuminate. Femoral process arising a little proximad of bases of solenomerite and tibiotarsus, its distal branch reaching to about three-fifths of length of telopodite, the caudal branch shorter, pointing caudad.

Female.- Antennal sockets separated by 2.15 times the diameter of a socket or by the length of the 2 nd antennomere. Relative length of antennomeres 2 to $6: 1.00,0.85,0.65,0.60$, 0.70 (6th to 8 th inclusive: 0.90 ). Sternites of middle somites as long as

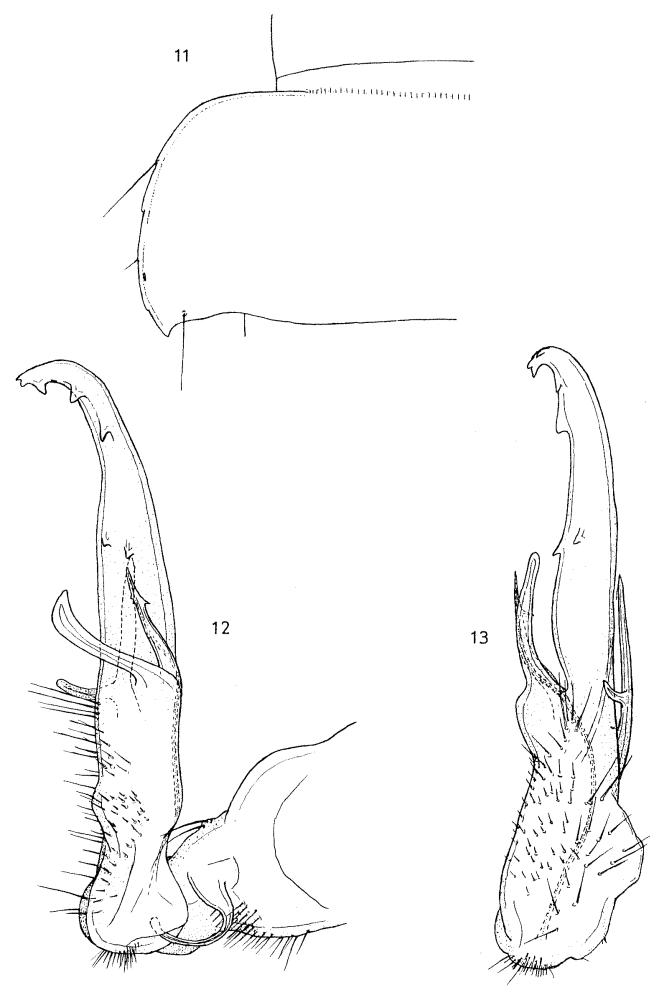

wide. Relative length of podomeres 2 to $6: 0.95,1.00,0.45,0.35,0.85$. Epigyne with triangular plate without lateral projections. Coxae of 2 nd pair of legs medially expanded and with a medioterminal low cone.

Remarks

In the points not mentioned the description of Lissodesmus modestus applies.

This species is easily recognized by the configuration of the gonopods, by the abnormal distribution of the pores, and by the absence of a premarginal furrow al ong the caudal margin of the paranota. In the outline of the paranota it comes closest to L. adrianae n.sp., but differs in the less curved anterior margin.

\section{Lissodesmus margaretae n.sp.}

Material

Lake Augusta, 25.IV.1979 [on cushion plant], Tasmanian Department of Agriculture 19A17, $\sigma^{\pi}$ holotype, 6 o, 1 q (fragm.), 2 juv. $q$ (19 somites), 1 juv. $q$ (18 somites) paratypes. 
Description

Colour.- Pale brownish yellow (probably decoloured); the head, antennae, collum and anterior part of metatergites areolate with darker pigment.

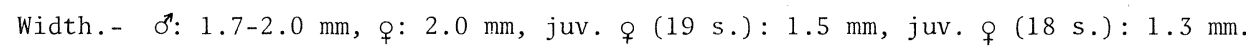

Head and antennae.- Clypeus moderately impressed towards the labrum; its 1atera1 border straight, with a faintly indicated emargination towards the labrum. Antennal sockets weakly impressed at the anterior side, separated by 2.2 times the diameter of a socket or by 1.1 times the length of the 2 nd antennomere. Relative length of antennomeres 2 to $6: 1.00,1.00,0.65,0.70,0.85$ (6th to 8 th inclusive: 1.05 ).

Collum.- A little narrower than the head, subsemicircular in dorsal outline. Anterior border widely convex, gradually little more convex towards the lateral sides, and laterally widely convex or almost straight. Posterior border scarcely emarginate towards the lateroposterior edge. Lateroposterior edge rather widely angular, subacuminate, not at all produced. Lateral border and laterocaudal border with a fine marginal rim, vaguely interrupted at lateroposterior edge. The lateral border with three small but distinct teeth. Surface with some long hairs caudad of the transverse series along the anterior margin. The long hair near the lateroposterior edge a little more remote from the lateral and caudal borders than in the other species.

Paranota. - Second somite with the lateroanterior edge widely subangular, rather narrowly rounded, marked by a small but distinct tooth. Lateral border with three small but distinct teeth, each of them often bearing a hair. Posterior border straight. Lateroposterior edge widely angular, acuminate, not at all produced caudad. Marginal rim narrow, the premarginal furrow of lateral border merging with the furrow of the posterior border. In lateral aspect the paranota of the 2 nd somite are widely concave, concavity upwards. Paranota of $3 \mathrm{rd}$ somite with the anterior and lateral borders more narrowly rounded than in the 2nd somite. The lateroanterior edge almost absent; the anterior and lateral borders merging by a narrower rounding. Lateral border with three small but distinct teeth. Posterior border faintly emarginate. Lateroposterior edge a little less widely angular than in the 2nd somite, not produced caudad. Paranota of 4 th somite with the anterior and lateral borders each a little less convex than in the 3 rd somite. Posterior margin straight, the lateroposterior edge widely angular as in the 3rd somite but slightly produced caudad. Paranota of 5 th and subsequent somites (fig. 14) with the anterior border rather narrowly rounded, shouldered a little at base up to about the 16th somite, and merging gradually in the lateral border which is quite weakly convex and diverges a little caudad. The marginal rim thin, with three small but distinct teeth. Posterior edges about rectangular becoming a little acutely angular towards the caudal end of the body. Posterior border faintly concave, more strongly emarginate quite near the lateroposterior edges. Lateroposterior edges weakly produced and scarcely projecting behind the margin of the somites, except in the 17 th and 18 th somites where they project a little behind the margin. Pores facing 1 aterad and a 1ittle dorsad, scarcely caudad. Lateral and posterior premarginal furrows connected, but indistinctly so in the poriferous somites. In lateral aspect the upper margin of the somites is concave, especially near the posterior end of the poriferous paranota.

Sternites and legs.- Sternites of middle somites longer than wide (ratio 1.2:1.0). Sternite of 5 th somite widely and rather deeply transversely concave in the caudal half. Sternite of the 7 th somite with the lateral margin of the gonopod aperture rather strongly raised as a rounded lobe. Legs with the femora ventrally scarcely arched; the tibiae ventrodistally a little inflated. Prefemora and femora becoming gradually more slender caudad of 7 th somite and almost not incrassate in the second half of the body. Relative length of podomeres 2 to $6: 0.85,1.00,0.30,0.30,0.95$.

Anal somite.- Epiproct triangular, rather short, with the sides weakly concave, not parallel towards the end. Paraprocts with setae on weak tubercles. Hypoproct truncate triangular, the setae on the edges of the almost straight caudal margin.

Gonopods (fig. 15).- Telopodites in situ reaching a little in front of the 6 th sternite, characterized by the branches diverging from the main axis instead of being more 


\section{C.A.W. Jeekel}

or less parallel. Prefemur anteriorly a little swollen just distad of the base, setiferous up to half the total length of the telopodite. Prefemoral process bearing a large uncus halfway and a smaller one more distally; the apex trifid, curving a little caudad. Solenomerite arising about halfway the length of the telopodite, reaching to about four-fifths of length. Tibiotarsus spiniform, slenderly tipped, arising a little distad from the base of the solenomerite, and much more caudad than in the other species, reaching almost as far as the solenomerite. Femoral process arising from about three-quarters of the length of the telopodite, splitting into two branches: the distal branch apically fringed, the caudal branch smaller, acuminate, both curving a little caudad.

Female.- Antennal sockets separated by 2.35 times the diameter of a socket or by 1.2 times the length of the 2 nd antennomere. Relative length of antennomeres 2. to 6: 1.00, $0.85,0.70,0.65,0.90$ ( 6 th to 8 th inclusive: 1.15 ). Sides of anterior somites not notably granular. Sternites of middle somites longer than wide (ratio $1.2: 1.0$ ). Relative length of podomeres 2 to $6: 0.85,0.85,0.35,0.35,1.00$. Coxae of 2 nd pair of legs broad, medially expanded and rounded, with an almost abortive mediodistal cone; no caudal process. Epigynal plate low triangular, laterally quite weakly emarginate, and without lateral elevation.

Remarks

In the points not mentioned the description of Lissodesmus modestus applies.

This is a small species like $L$. alisonae n.sp. from which it is easily distinguished by the quite different structure of the gonopods and the more distinct serrulation of the lateral margin of the paranota.

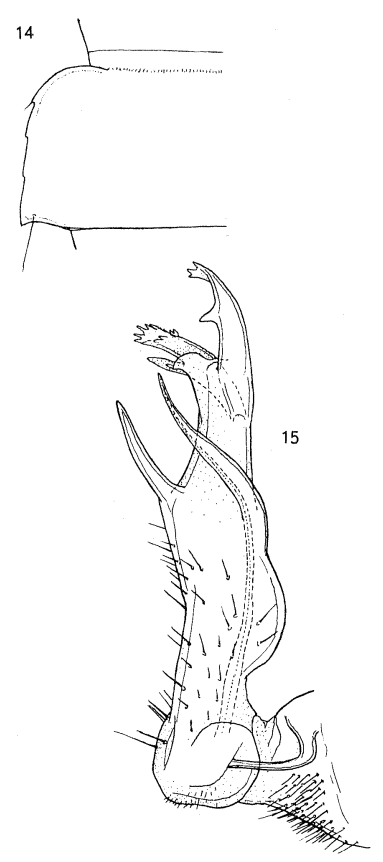

FIGS 14-15 Lissodesmus margaretae n..sp. 14 left side of 11 th somite of $\sigma^{A}$ paratype, dorsal aspect. 15 - right gonopod of $\delta$ holotype, medial aspect.

The species is kindly dedicated to Mrs Margaret A. Williams, entomologist at the Department of Agriculture, Hobart, who made the material available for study.

\section{ACKNOWLEDGEMENTS}

This paper is based on data accumulated through the aid of a grant (WR 87-157) from the Netherlands Foundation for the Advancement of Tropical Research (WOTRO).

\section{REFERENCES}

Carl, J., 1926: Diplopoden von Neu-Caledonien und den Loyalty-Inseln. In Sarasin \& Roux (Eds) : NOVA CALEDONIA. Zool., 4: 369-462.

Chamberlin, R.V., 1920: The Myriopoda of the Australian Region. BuZZ. Mus. comp. Zool. Harv., $64: 1-269$.

Hoffman, R.L., 1980 (1979): CLASSIFICATION OF THE DIPLOPODA. Muséum d'Histoire Naturelle, Geneva: $1-238$

Jeeke1, C.A.W., 1968: ON THE CLASSIFICATION AND GEOGRAPHICAL DISTRIBUTION OF THE FAMILY PARADOXOSOMATIDAE (DIPLOPODA, POLYDESMIDA). Privately printed, Arnsterdam: $1-162$. 1980: Records of Diplopoda of the order Polydesmida from the Fiji 1sıands. Ent. Ber., Amst., 40: 122-127.

, 1981: Australia Expedition 1980: legit C.A.W. Jeekel and A.M. Jeeke1-

Rijvers. List of collecting stations, together with general notes on the distribution of millipedes in eastern Australia and Tasmania. Versl. techn. Gegev. Inst. taxon. Zoor., 30: 1-59. 
Jeekel, C.A.W., 1982: Millipedes from Australia, 4: A new genus and species of the family Dalodesmidae from Tasmania (Diplopoda, Polydesmida). Bull. zool. Mus. Univ. Amst., 9: 9-15.

Johns, P.M., 1964: The Sphaerotrichopidae (Diplopoda) of New Zealand. I. Introduction, revision of some known species and description of new species. Rec. Canterbury Mus., 8: 1-49.

Lawrence, R.F., 1953: A revision of the Polydesmoidea (Diplopoda) of Natal and Zululand. Ann. Natal Mus., 12: 291-350, pl.IX.

Silvestri, F., 1910: Descrizioni preliminari di nuove generi di Diplopodi. I. Polydesmoidea. Zool. Anz., 35: 357-364.

Verhoeff, K.W., 1936: Die Sphaerotrichopidae der südlichen Halbkugel und ihre Beziehungen. Zool. Anz., 114: 1-14.

1939: Über südafrikanische Polydesmoideen. Ann. Natal Mus., 9: 173-201.

1940: Aliquid novi ex Africa. I. Polydesmoidea und Colobognatha.

Zoot. Anz., 130: 104-119.

, 1941: Über Gruppen der Leptodesmiden und neues system der Ordo

Polydesmoidea. Arch. Naturgesch., (N.F.) 10: 399-415. 